\title{
The United States-China Mutually Assured Distrust
}

\author{
Jalel Ben Haj Rehaiem ${ }^{1, *}$ \\ ${ }^{1}$ Department of English Studies, Institute of Applied studies in Humanities, Gafsa, Tunisia \\ *Correspondence: Department of English Studies, Institute of Applied studies in Humanities, Gafsa, Tunisia. E-mail: \\ jalelrehaiem@gmail.com
}

Received: April 17, $2017 \quad$ Accepted: May 26, $2017 \quad$ Online Published: July 3, 2017

doi:10.5430/sass.v4n2p1 URL: https://doi.org/10.5430/sass.v4n2p1

\begin{abstract}
The $21^{\text {st }}$ century geopolitical developments in East Asia have placed the People's Republic of China (PRC) in a prime position to play a major role in the complexities of Asia-Pacific politics. China is a rising power, but whether it is going to be a status quo power or a challenging one remains to be seen. With the world's largest population, the world second economy and a modernizing military force, China theoretically has room to have a say in the revision of the security order in East Asia, which has been dominated so far by an already controversial Cold War alliance between the United States and Japan and a new American pivot to Asia since former President Obama announced his new Asia strategy in Canberra in November 2011.

As China's prowess grows, so do percolating challenges to U.S. prominence in the region. The gap between what China intends to do with accumulating power and how it is perceived in Asia and the West alike has created what this article calls China's trust dilemma with the United States.

The distrust between Beijing and Washington has ostensibly plagued their relationship and may continue to dominate their interaction for the unforeseeable future; an interaction between an already established world hegemon and a rising regional player that is allegedly aspiring to challenge and even replace its rival, at least in Asia for the time being.

As this article seeks to study the implications of the rise of the People's Republic of China (PRC) as a world power and the trust dilemma China's rising might is incurring, this work,in its attempt to fathom Beijing's strategic intents, adopts the security dilemma framework whichrefers to a situation wherein two states may be drawn into conflict, possibly even war, over security concerns, even though none of them actually seeks confrontation.
\end{abstract}

Keywords: China, United States, security, hegemony, East Asia, distrust, political science

\section{Introduction}

This article starts from observing the outcome of an October 2016 survey released by the Pew Research Center ("Chinese Public Sees More Powerful Role in World, Names U.S. as Top Threat", October 5, 2016)(Note 1)on, among other issues, mutual perceptions between the Chinese and the Americans. When we learn from this survey that "only 30 percent of Americans say they have a "great deal" or a "fair amount" of trust in China, while a full quarter of Americans do not trust China "at all", it is clear that the most serious problem for U.S.-China relations is a lack of trust and not a lack of trade. And the trust issue between the two countries is all that this work seeks to fathom qualitatively, and not quantitatively.

On the Chinese side, the figures are more ominous. More than 45 per cent of those surveyed in China perceive the United States as a major threat to their country, and 52 per cent think the United States is preventing China from becoming as powerful as America. The survey shows that 77 per cent of the Chinese people is concerned even about their way of life which, they believe, needs to be protected against foreign influence (ibid), reflecting a great deal of distrust of the United States, especially with regards to China's rise and all that this unfolding geostrategic development is incurring.

The implications of the rise of the People's Republic of China as a world power and the trust dilemma China's rising might is eliciting has become one of the most intriguing paradoxes of today's world politics. The more powerful 
China becomes, the more it is perceived as threatening. What China will do with accumulating huge economic and financial power, with its attendant military prowess, has bedeviled East Asian scholars and strategists. Whether China will seek to translate its growing economic power into a commensurate power projection capability in a region marked by a lingering memory of Japan's colonialism from the end of the $19^{\text {th }}$ century well into the first half of the $20^{\text {th }}$ century, and plagued by a series of territorial disputes in both the East and South China Seas with most of China's neighbors, is the most urgent question in today's U.S.-East Asia security debate, in view of the recently unexpected of Donald Trump's win of the presidential elections in the United States.

Chairman Mao once famously said, "Political power grows out of the barrel of a gun", but that was almost half a century ago. Now, China is the world's second largest economy. Though downgraded from 7.1 to 6.5 per cent projected growth in 2017 after the dramatic fall of oil prices since 2015, the Chinese economy is expanding at triple the rate of the U.S. economy and six times that of Japan. By 2020 it is highly likely that China will be the world's largest economy, if not already. Indeed, according to the World Bank's International Comparison Program, China's economy will surpass that of the United States around this year 2017. As the World Bank reports, the Chinese economy was 87 per cent of America's in 2010, and as it has grown 24 percent ever since, while the American economy grew only 7.5 per cent. The report indicated that China's economy would likely pass that of the United States by 2017(Note 1). Today, 124 countries count China as their largest trade partner, compared to just seventy-six for the United States.

As we are approaching the 2020 target date when China's economy is expected to bypass that of the United States, and at a time China is perceived as America's enemy number one by at least 53 per cent of Americans (Note 2), the issue of the nature of China's rise has become more debatable than ever, and from the standpoint of a range of theories. But it is imperative to understand that we are subconsciously trying to predict the future here. As Thomas Hobbes put it well: "The present only has a being in nature; things past have a being in the memory only, but things to come have no being at all"; therefore, we are talking about something that has "no being" so far and therefore we need a theoretical framework to dissect the puzzle of China-America trust deficit.

\section{Theoretical Background}

China's rise has elicited more theoretical controversy than consensus as to where Beijing is heading with this enormously growing economic and trade leverage under a world and regional order largely dominated by the United States and its allies. Across the board of analyses and guessing we can mention Thomas Christensen's characterization of China as the 'high church of realism' (Christensen, The New York Times, July22, 2015) to Alastair Johnston's perception of the People's Republic of China (PRC) as 'a hard-realpolitik state' (21), up to Mearsheimer's doubts on whether China would continue to rise as a united nation, given its complex ethnic and social discrepancies (Personal Interview with John Mearsheimer, Chicago University, April 2006). As for political science as a discipline, it is in a bewildering position wherein the flood of political theories has added to the complexity of the question; a position very much reminiscent of its failure to predict the Soviet demise back in the early 1990s.

It is clear that realism alone, which pronounces the centrality of power in understanding international relations, has ostensibly failed to explain the theoretical question of China's trust dilemma with the United States. Constructivism in its turn sets to integrate the material and social identities of states into "a unified analytical perspective that treats the domestic and the international as two faces of a single social and political order"(Reus-Smit, 2005, 194-5).As realist power cycle theory sheds light on material capabilities, such as military and economic attributes (Kissane 105-121), constructivist social and geographic variables can also provide clues to analyzing whether China can build a trust relationship with the United States and will rise peacefully and "responsibly" or it will seek to reshape the world order in a way that accommodates Beijing's interests. A point for sure is that "while realism and constructivism are generally seen as polar opposites, the [challenging] study of China['s future intentions] shows how closely linked they are" (Gilley 2011). Most obviously, realism is not the only way to understand China's foreign policy or future posture, but it is true that constructivism also fails as an explanation of Chinese security dilemma.

Therefore, the span of common social and cultural attributes between the United States and China, which are key drivers in interstate interaction from a constructivist standpoint, is dime and even nonexistent. On the opposite, historical facts show that, since the 1844 Sino-American Wanghia Treaty and its attendant and humiliating extraterritoriality clause, and as the Pew Research Poll also clearly demonstrates, interfacing domestic and political analysis here can only be misleading, to say the least. 
Whether China's rise would be disruptive to the existing Pax Americana in East Asia would basically depend on Beijing's intentions, as "disruptive" or hegemonic acts are usually approached through the prism of intentions because "States can never be certain about the intentions of other states, [since] intentions are inside the heads of leaders and thus virtually impossible to see and difficult to measure" (Mearsheimer, the National Interest, October 25, 2014). Yet the central question remains how we expect China to behave as it grows more powerful. How should the United States and China's neighbors react to the looming security concerns Beijing is ostensibly posing? Does this lead the argument to the vicious circle of security dilemma?

In view of the significance of the notion of security in determining the nature and the outcome of interactions between states, it is almost inevitable to endanger other states' security when one state seeks to increase its own security. This is what John Herz calls a "security dilemma"(Note 6) (231-35), which refers to a situation in which one state takes action to enhance its own security only to have this action seen as threatening by other states; the result is that the latter engages in "defensive" countermeasures that intensify the former's sense of insecurity (Buzan 83). The dilemma arises from the fact that because of this process, actions taken to enhance one's security can paradoxically end up diminishing it. There is a dilemma for the second state in that if it regards the first state's action as offensive and takes no countermeasures, it leaves itself vulnerable, whereas if it responds vigorously, it may exacerbate the first state's insecurity (qtd in Williams et al. The Dictionary of 20th Century Politics 601), hence comes the inevitability of the vicious circle governing security dilemmas.

As security dilemma is a feature of anarchy in international relations, it can be exacerbated by perceptions based on false information or on inherent bad faith, which has generally characterized the relationship between rising and status quo nations, such as the case of the United States and China. Consequently, a security dilemma usually leads to what Barry Buzan calls a "security complex". It is a situation where "a group of states whose primary security concerns link them together sufficiently closely that their national security cannot realistically be considered apart from another" (Buzan 62) as it is the case of the burgeoning United States-ASEAN security relationship, in view of the perceived militarization of the South China Sea by China, such as the Sunylands United States-ASEAN Summit in February 2016.

Largely seen as a move to counter China's rising leverage in Southeast Asia, President Obama hosted the first US-ASEAN Summit early this year in California to further consolidate the trade and economic interaction, besides the security factor, between the two sides. "Washington is sparing no efforts to expand its leverage with ASEAN amid China's growing regional influence. Divergence and competition between the two major players seems set to intensify, since both economies and their business communities want to seize the initiative in developing a more profound and mutually beneficial economic relationship with ASEAN" (Ting, March 30, 2016). The Sunylands Summit can only be perceived within the context of a rivalry relationship between the United States and China; a rivalry over winning over the allegiance of China's neighbors who are seeking to ally themselves with the more reassuring side.

The sense of threat often pushes states to ally with the stronger player to make up for their weaknesses, such as the case of the 1950 Sino-Soviet Alliance. Mao Zedong wrote in June 1949: "it was the possibility of military intervention from imperialist countries that decided the necessity of China allying itself with socialist countries" (Chen 65). Since a rising China is perceived as a potential hegemon in opposition to a United States, an established predominant power and a security guarantor, and in an atmosphere of anarchy governing international politics, the security dilemma is most applicable.

As advanced before, the security paradox, which is endemic to international relations, is about the situation whereina state tries to consolidate its self-defense, it paradoxically sends alarming signals to its neighbors about its intentions, and therefore arouses their fear and suspicion. In his account of the Peloponnesian War between Athens and Sparta, Thucydides said: "What made war inevitable was the growth of Athenian power and the fear which this caused in Sparta" (Thucydides 358-59). Although Athenians and Spartans had been allies against the invading Persians, they became arch enemies simply because Athens' growing power after the defeat of the Persians was taken in Sparta as a warning that the Athenians could direct their military power against the Spartans. Existing side by side without a higher authority to impose standards of conduct, Sparta felt threatened by any actual or perceived increase in Athens' power.

By the same token, the United States suspects that because China is growing stronger, it is highly likely that it is becoming more and more assertive and may therefore challenge Pax Americana in East Asia. As Former CIA Deputy Director Michael Morell told CNN's Erin Burnett: "China is a rising power. We're a status quo power. We're the big dog on the block ...They want more influence....Are we going to move a little bit? Are they going to 
push? How is that dance going to work out? This is a significant issue for the next 'President of the United States"(Note 7).

To borrow Cary Coolidge's 1910(Note 8) maxim that one nation controlling the world is as ancient as human spring, the theory of America's perceived decline and China's presumed rise has created a Chinese trust dilemma as to whether this rise would be peaceful or hegemonic. A few years ago, John Mearsheimer, the founder of offensive realism, told me during an interview with him in April 2006 that China could not rise peacefully (Note 9) and that Beijing was after controlling the world in accordance with his power quest theory advanced in his book The Tragedy of Great Power Politics. So, the idea that China will inevitably seek to assert itself regionally and internationally is already a debated prospect. As Beijing's trust dilemma is the focus of this work, "understanding and managing China's global resurgence will require both an appreciation of the multifaceted nature of the issue as well as an attention to political and security facts in China, which could transform its peaceful rise into a disruptive one" (Gilley, 2011, ps.795-811).

It is true that, China, as any rising state on the international arena, has barely been passive in the process of the metamorphosis of Asian politics; "and like any growing power Beijing will highly likely attempt to shape the pace and the terms of this process in its favor" (Burton, Sandra, et al. March 1997: 52). Regardless of how China will elbow its way on the world stage as a rising global power with global interests, that will deepen the level of mistrust between Beijing, on the one hand, and most of its Asian neighbors, especially Japan and the Philippines, and with the United States, on the other hand. The rise of China is not a matter of guessing now, nor China's ability to close the power gap with the United States in the near future; the question is what would happen then. While RAND, for instance, predicted that Beijing would close its power gap with Washington by around 2017 (Treverton and Jones 2005), Johnston and Chestnut put the cross-over at between 2030 and 2040(2009: 237-260).

Regardless of how accurate the guessing might be, there are now concerns not only in Asia but also in the United States that it is a matter of time for China "to become the dominant power in East Asia. It probably aspires as well to replace the United States at the top of the world hierarchy of power" as A D. Mclennan put it (52). The concern that China is bound to replace the American regional order is not only American; it is also a shared concern even by America's closest allies in Asia, especially Japan and Australia (White 2012, Johnson 2004, DiFilippo 2002). Canberra's 2013 Defense White Paper feared that China was already contesting American primacy in Asia and emphasized the "60-year old alliance" with Washington, while Singapore's patriarch Lee Kuan Yew reportedly blamed Washington for "giving China a free run in Asia" ("Mainstream", December 12, 2009).

\section{China's Hegemony Temptations}

As a matter of fact, "to fully understand [China's] developmental trajectory and international aspirations, and, more importantly, to have any control over them" (Mills, May 19, 2010), we need to consider China's economic and financial attributes that could tempt Beijing into going hegemonic, which a rising global power would incur, as the United Kingdom and the United States did respectively in the $19^{\text {th }}$ and $20^{\text {th }}$ centuries. The debate whether the world could trust Communist China with record economic and financial leverage has been fuelled by World Bank figures about China's economic performance and potential. As of Monday August 16, 2010 the Chinese economy became the second largest economy in the world at a value of \$1.33 trillion, while Japan's economy was valued at about $\$ 1.28$ trillion in the second quarter of 2010. China is bigger than those of its fellow BRICS countries (India, Russia, Brazil and South Africa) combined. In 1977, China accounted for just 0.6 percent of global trade; in 2012, it became the world's largest trading nation. Today, 124 countries count China as their largest trade partner, compared to just seventy-six for the United States (Bremmer, The National Interest, April 9, 2016). Today, China holds $\$ 3.21$ trillion worth of foreign exchange as of June 2016, which is the largest amount of foreign exchange owned by any central bank in the world, and in history as well (http://www.tradingeconomics.com/china/foreign-exchange-reserves).

Moreover, China's monopoly over rare earth minerals, which are crucial to a number of high-tech products, including aircraft, electronics and magnets, clean-energy products, such as wind turbines and electric cars, can further testify to China's increasing economic leverage. "China controls about $95 \%$ of global rare-earth supply and has been reducing its export quotas to secure greater control over prices, leading to a surge in prices over the past two years" (Wall Street Journal, December 28, 2011).And there are examples when Beijing used the rare earth minerals as a political and economic weapon to influence other countries' course of action. China had already slashed its export quota for rare earth materials to the United States by 30\%. (CNN Money Report, October 21 ${ }^{\text {st }}, 2010$ ). The Chinese Ministry of Commerce was not secret about Beijing's intent to "continue to implement restrictive measures on the mining, production and export of rare earth" (ibid). China using its rare earth monopoly as a political weapon was manifested in 
September 2010, for instance, when a Chinese vessel collided with a Japanese patrol around the contested Senkaku/Diaoyu islands, resulting in a diplomatic row between Tokyo and Beijing. Consequently, China cut off all exports of rare earth minerals to Japan, which fuelled suspicions about Beijing's increasingly bullying posture in Asia (The Telegraph, December 24, 2010).

Going one step back in recent history would further highlight the pace of China's über-economic leap in the last four decades. The findings could be used as a measurement unit of China's military potential in the attempt to explore Beijing's intentions about what it would do with such tremendously growing economic and financial prowess. From the mid-1980s through the mid-1990s, for example, China's real gross domestic product (GDP) per capita grew at a rate of 6.9 percent per year, a growth experience exceeded only by Thailand and the Republic of Korea during the same period (APO Production Databook, Asian Productivity Organization, 2012: 15-32). China's overall growth rate remained robust even in the face of the terrible economic crisis that swept through East and Southeast Asia during 1997 and 1998 (Rosenberg 229-62). By 1999, China had the seventh largest economy in the world, surpassed only by the United States, Japan, Germany, France, the United Kingdom, and Italy. The World Bank, which based its estimates on purchasing power parity measurement, projected that by the year 2020 China could easily have the largest economy in the world (United Nations Department of Economic and Social Affairs, "Population Division Population Distribution, Urbanization, Internal Migration and Development: An International Perspective”, 2011:81-109).

Consequently, China's current growth rate of around 6.7 percent, an industrial production that is growing at an annual rate of 15 percent, and a capital investment in dollar terms in China exceeding that in the United States by a 3.5 ratio, urban residential real estate growing at more than 25 percent a year, are all indicators of China's growing economic and financial weight (National Bureau of Statistics, "China GDP Annual Growth Rate1989-2016", July 15, 2016). This has led to historic social mobility in a communist country in terms of wealth accumulation. "According to Credit Suisse, a third of the Chinese population now has wealth of between $\$ 10,000$ and $\$ 100,000$, compared with less than 7 percent of Indians. More than 17 million Chinese have wealth above \$100,000" (The Daily Beast, Aug 14, 2011). In 2016, The Hurun Report said that China now has 568 billionaires versus the United States' 535 ones, giving it the largest population of billionaires in the world at large (http://www.cnbc.com/2016/02/24/china-has-more-billionaires-than-us-report.html).

With the world's largest foreign exchange reserves of 3.2 Trillion U.S. dollars, and\$1.159 trillion of Treasury securities (The Wall Street Journal, July 29, 2011), China seems to be in the ideal position to rescue the West from its self-inflicted economic injury. After all, it was the United States with the biggest economy in the world that asked China, a developing country, to rescue America's financial melt down by refraining from devaluating its Yuan. If China's currency help with the 2008 America's financial crisis reflected anything, it reflected that China is accumulating an increasingly huge financial and economic leverage in the global market and in US politics; a leverage Beijing has tried to convert into political gains (Sutter 2010, Holodny, Business Insider, August 18, 2015).

Paradoxically, as China is being incrementally dependent on trade and imported energy, it will therefore need a strong military to secure the sea lanes through Southeast and Southwest Asia open to Chinese trade and energy imports; and Beijing's increasing economic and financial clout will allow China to increase the commensurate military capabilities (Note 10) it needs. By 2020-25 China will be relying heavily on imported oil and other energy resources, from Central Asia, the Middle East, and Sub-Saharan Africa, which currently provides 8 per cent of the world's daily oil consumption, and has almost 12 per cent of the world's oil reserves (Venkatshamy 2012: 13-40).

Subsequently, energy contest not only in Asia but also in the world will almost necessarily result in more security issues between the United States and China, adding to Asia's security complexities, as the hunt for energy will highly likely pit them against each other in the Middle East, Africa, Latin America, and even in North America. As David Zweig the Director of the Center on China's transnational relations at the Hong Kong university of Science and Technology put it, "a big test of the U.S.-China relationship may come if China's current economic growth and need for resources push it to expand its military influence(Zweig \&Jianbai: 33).

Indeed, Gen Xu, a military adviser to the Chinese government says that "the development of our armed forces is connected with the development of our economy...In energy supplies and trade we now have interests that span the globe....So our military strength needs to match the range of our economic and diplomatic activity" (BBC News Asia-Pacific, June 8, 2011). As a result, the Chinese do have a deep interest in increasing their air and naval capabilities for power projection reasons so as to ensure that China's economic security is not disrupted by another major power, particularly Japan and the United States.

As China's economic and military attributes continue to increase dramatically, "building a strong navy that is commensurate with China's rising status is a necessary step and an inevitable choice for the country to safeguard its 
increasingly globalized national interests" (Duong, July 20, 2011). As a consequence, China's neighbors may in turn seek to enhance their own military defenses, leading East Asia down the path of a regional arms race that would aggravate tensions between the region's main actors and deepen misperceptions among them. The crux of the matter is that the continued rise of China will likely create new Chinese interests and capabilities, which could be perceived, rightly or wrongly, as a threat to the interests and security of other East Asian drivers, especially the United States and Japan; thus opening up a vicious circle of misperception and miscalculation, which takes the discussion back to the trust dilemma China has to handle. So will China speak softly while building bigger sticks, or it has already deepened its trust dilemma with its regional and global rivals, namely Tokyo and Washington?

Beijing's behavior, particularly in the South China Sea from 2008 to December 2013 and up to the most recent China-Philippines judicial showdown over the Scarborough Shoal in July 2016, has provoked a regional united front against it; a front supported by a United States that has sought to legitimize its regional military presence by playing the China card and inflating the China threat. The Sunnylands Summit is an example of the Unites States and China's neighbors' efforts to consolidate a unified reaction to Beijing's alleged hegemonic moves in the region.

From the U.S. perspective, there is a considerable evidence (Dingli et alt, 2016) that Chinese leaders would like to develop the capability to push the U.S. Navy beyond the "first island chain," which is usually taken to include the Greater Sunda Islands, Japan, the Philippines, and Taiwan (Trinity RS Series, Wake Round 8 - Trinity RS File Name 2013-2014). If this were to happen, China would be able to seal off the East China Sea, the South China Sea, and the Yellow Sea, and it would be almost impossible for the U.S. Navy to reach Korea in the event of war. There is even talk in China about eventually pushing the U.S. Navy beyond the "second island chain," which runs from the eastern coast of Japan to Guam and then down to the +6 (ibid). It would also include the small island groups like the Bonin, Caroline, and Marianas Islands. If the Chinese were successful, Japan and the Philippines would be cut off from American naval support (ibid). Such suspicions, even if they are about intentions, can play in "Beijing's rivals [who] will continue to point to its large collection of territorial disputes, and its defiant approach on handling them, as evidence that China is not a peaceful actor in the region" (Miller 2012).

China's effort to modernize its military, regardless of its intentions, whether defensive or offensive, have been interpreted both East Asia and the U.S. as preparing for future hegemony in Asia (Gertz 2005). And this fits into Reynolds' theoretical framework of security dilemma that if state A tries to seek more power to maximize its security (1994), it almost automatically provokes suspicion from its neighbors, a prospect that could lead to an arms race which generally results in armed conflicts based on a pre-emption calculations (Andrews 2006).

With a declining American supremacy in Asia-Pacific and Japan's sloppy slope economic stagnation, Abenomics notwithstanding, China's moves, even of a defensive character from the Chinese standpoint, are now a subject of guessing by the United States and its allies in the region. Whether it is the beginning of a new era of China's assertiveness in Asia and the world at large has caused the proponents of the China-threat thesis to feel vindicated about their previous predictions of the coming conflict with China (Berntsien et alt., 1998). As the balance of power is shifting and new forms of political and economic regionalism are emerging in Asia, it is believed that the way for China to become a fait accompli regional and even world power is now burst open (Singh \&Dürkop2009). Indeed, the advent of the $21^{\text {st }}$ century and with it China's compelling economic growth may have given birth to a new concept of 'China's Century'; a concept that is fueled by the suspicion of China becoming an increasingly assertive world superpower, which has further deepened Beijing's trust dilemma in dealing with its Asian neighbors.

As a matter of fact, China's potential security threat in East Asia has been felt from Beijing's behavior in the East China Sea, for instance. The Sino-Japanese series of incidents from September 2010 and up to August 2016 over their ongoing conflict in the oil-rich Senkaku/Diaoyu Islands are a good example as to the trust dilemma China is facing in its own neighborhood. The recurrent sovereignty standoffs over the East China Sea jurisdiction controversy brought China and Japan to the brink of a military showdown in 1995, 1999, 2004, 2010, and more recently in July 2016 when China, in an attempt to deflect attention from the Hague jurisdiction over its claim of the 9-dash Line in the South China Sea, sent its vessels into the Senkakus' exclusive economic zone.

Moreover, on the morning of 7 September 2010, for example, a Chinese fishing trawler collided (Minjinyu 5179) with Japanese Coastguard vessels in the vicinity of the Senkaku/ Diaoyu Islands (Asia Times online, September 16, 2010), resulting in a diplomatic crisis between the two nations. China suspended its exports of rare earth material to Japan, and threatened tit for tat measures against Tokyo. Since September 2012 the Sino-Nippon conflict over the Senkaku/ Diaoyu Islands has been simmering, even in the aftermath of the change of political leadership in both Beijing and Tokyo in March and February 2013 respectively.

Tension increased when Japan, which controlled the islands, said it had bought them from a private owner, ignoring 
warnings from China which responded by sending two patrol ships to reassert its claim. Besides the Chinese Foreign Ministry condemnation of what it characterized as "grave condition", the Liberation Army Daily, the chief newspaper of China's military, warned Japan that China's forces were ready to defend its sovereignty. "The Japanese government should not place its hopes in its so-called air and sea advantage. Chinese and Japanese forces have exchanged blows before. Nowadays, China's defense forces have achieved advances that nobody can belittle" said Luo Zhaohui, the head of the Chinese Foreign Ministry's Asian department (Release of the Ministry of Foreign Affairs of the People's Republic of China, September 12, 2012-http://www.fmprc.gov.cn/eng/).

As a reaction to Japan's buying three out of the five Senkaku Islands in September 2012, China unilaterally declared its own Air Defense Identification Zone (ADIZ) on November 23, 2013 over the contested islands. "An ADIZ is a publicly defined area extending beyond national territory in which unidentified aircraft are liable to be interrogated and, if necessary, intercepted for identification before they cross into sovereign airspace" (Welch, Foreign Affairs, December 9, 2013). Although the United States and Japan rejected China's ADIZ arguing that it was illegal and unilateral, Beijing's ADIZ endeavor itself could tell a great deal about what China might do when stirred or ostensibly provoked, which deepened concerns about China's future intents not only in the East China Sea but also in the South China Sea where China has territorial disputes with at least five of its neighbors. Regardless of China's immediate neighbors disregarding its ADIZ, the reverberations of such Chinese move also shed doubts all over Southeast Asia as to Beijing's real penchant for going hegemonic and assertive in the region.

Though largely seen as an attempt to play to domestic nationalism, China's ADIZ was construed as a provocative step by both Japan and South Korea because it incorporated water claims by Tokyo and Seoul. "The reality is that the new ADIZ is part of a longer-term attempt by Beijing to chip away at the regional status quo and assert greater control over the East and South China Seas" (Green, Foreign Affairs, December 2, 2013). It was clear that China's East China Sea ADIZ played well in the hands of the China-threat camp and prompted the United States, Japan and South Korea to send their war planes through China's new ADIZ. Washington in its turn sent two B-52 bombers out of Guam to fly through the new defense zone, which showed Beijing's impotence in defending its self-declared exclusion zone over the Senkakus. Joseph Biden, the former US Vice President, during his visit to China was told to "leave no doubt [in China's mind] that the United States [was] prepared to work with regional allies and partners to ensure Beijing understand that its attempts at coercion will not work...[and that America's allies'] problem is our problem, not just because we are allies but also because this moment could determine how China uses its growing power" (ibid). In short, China's ADIZ brought about more liabilities than assets to China, as it brought back the issue of its territorial disputes in the South China Sea to the scene.

The South China Sea is another hot spot in the China-Southeast Asia relations. The South China Sea waters accommodate major energy and a five trillion dollar trade volume, affecting much of the world's economy. It is "a vital sea lane for Chinese energy from the Middle East and Africa and also a potential source of oil and gas in its own right" (Santolan, May11, 2011). In April 2015, during the Shangri-La Dialogue in Singapore, U.S. Secretary of Defense Ashton Carter highlighted the importance of regional security in Southeast Asia - not just for regional contestants in the South China Sea but for all states, given the importance of freedom of navigation and overflight stakes there. Former President Obama had reiterated this view at the Sunnylands Summit with ASEAN leaders in February 2016 (Walters, The National Interest, April 15, 2016).

The standing dispute over the Spratly and the Paracel Islands in the South China Sea with more than ten nations in Southeast Asia is not a good sign of mutual trust between China and its neighbors. On the ground, China has taken several of the islands and reefs in the South China Sea. The row in the South China Sea started in 1988 when Beijing seized seven islands from Vietnam after a brief naval clash. In 1995, China occupied Mischief Reef, which has been claimed by the Philippines, and placed markers on several other reefs in the area claimed by Manila. A few stand-offs between Chinese and Philippine vessels have occurred since then. Moreover, the Chinese have continued to build on Mischief Reef (South China Morning Post, on-line version, February 16, 2001).

China's actions against the Philippines at the Reed Bank in the South China Sea in March 2011 and those against Vietnam's survey ships in May and June 2011 took place within a striking distance from the Philippine and Vietnam coasts respectively. The most recent China-Vietnam row over Beijing's oil rig on the Chisha Island in the South China Sea in the summer of 2015 is a case study that has clearly shown how fast a minor naval incident could spiral into a full and open diplomatic row, a trade war and even a popular reaction between the two countries. "China's drilling rig is also a political statement of Beijing's resolve and capability to control and exploit the South China Sea and deny it to others -While exploring oil in the disputed waters, the \$1 billion oil rig is supposedly drilling a big hole in Washington's "pivot strategy" insofar as it undermines Washington's credibility as regional security anchor 
or security guarantor" ("China and Strategic Imbalance", The Diplomat, July 14, 2014"). The Chisha incident was construed in Southeast Asia as an attempt from Beijing to show to its weak neighbors that they were indeed helpless and would rather acquiesce to the new political order in the South China Sea, which brings the discussion of China's trust issue back on stage. Such China's assertive actions have set off alarms in the region as to whether China's commitment to a peaceful resolution of its territorial disputes with its neighbors is still credible.

Generally, China has taken several steps to militarize the artificial islands it constructed in the Spratlys. Beijing has built radar stations to keep watch over regional air and sea traffic in the South China Sea. It has also built long runways on several islands and deployed anti-aircraft missiles and fighter jets. In February 2016, the Chinese military deployed advanced HQ-9 surface-to-air missiles to Woody Island in the Paracels (Walters, The National Interest, April 15, 2016), which can have strategic implications on the balance of power in the South China Sea, such as giving China the military edge in the region. "If the Chinese should deploy fighters to those airfields, they would be able to conduct air patrols over 90 percent of the area" (Walters, The National Interest, April 15, 2016).

The other concern about China's intents in the South China Sea is a possible Air Defense Identification Zone (ADIZ) in the aftermath of the China vs. Philippines verdict on July 12, 2016 by the Hague-based Permanent Court of Arbitration which rejected Beijing's claim to the 9-dash line(Note 11) in the South China Sea. A Chinese ADIZ in the South China Sea "could cover all territory within the Nine-Dash-Line area or specified areas within the South China Sea, such as the Paracel and Spratly Islands. It may also extend over Scarborough Shoal; a main focus in the arbitration and a site that Adm. John Richardson recently identified as 'a next possible area of [Chinese] reclamation"' (Walters, The National Interest, April 15, 2016). As each day seems to bring news of another Chinese construction in the South China Sea, China "has effectively unilaterally annexed $80 \%$ of the sea's area, through which passes \$5trillion of world trade annually" (ibid).

However, the China trust problem with the United States extends far beyond Beijing's conduct in the South China Sea. The concerns about China's trust deficit are further reinforced by the quality and quantity of weaponry China is trying to acquire, which further complicates China's attempts to dispel the impression of a threatening China and build a trustworthy image of a "responsible" stakeholder (Lee, Project 2049 Institute, July 5, 2016). "The Chinese are investing in...nuclear powered submarines; a clear signal that they intend not only to protect their coasts but also to expand their influence far out into the Pacific" (Kaplan 50). Hence, alarmists are gaining ground in inflating China's security threat to the U.S.-led status quo in East Asia, as China's economic dynamism can translate into a military disparity with its neighbors.

China is already the dominant naval power in East Asia, and is developing new weaponry which shows China's broadening strategic ambitions. General Xu Guangyu, a retired from the PLA's headquarter said that "an aircraft carrier is a symbol of the power of your navy... [and] China should at least be on the same level as other permanent members of the U.N. Security Council who have carriers" (BBC News Asia, June 14, 2011). Indeed, China inaugurated its first aircraft carrier, Lioning, which though still unarmed, is now patrolling the South China Sea waters, and even starting to push back against the U.S. maritime predominance in the area, resulting in some maritime incidents between the two sides.

On December 23, 2013 a Chinese vessel, PLAN, sailing along with the Liaoning, swung across the bow of the cruiser USS Cowpens in what became known as the "Cowpens Incident" (The Diplomat, December 17, 2013). The Liaoning left its homeport Qindao on its maiden mission to the South China Sea, another hotspot in the Western pacific that has witnessed many military skirmishes and even confrontations between China and some of its neighbors, especially the Philippines. Because the Liaoning was unarmed, it was accompanied by two destroyers, the Shenyang and Shijiazhuang, and two missile frigates, Yantai and Weifang. There were two contradictory versions from Beijing and the United States. Beijing argues that the USS Cowpens had entered within a forty-five kilometer inner defense layer of the Liaoning carrier group; Washington, however, claims that the USS Cowpens was in international waters, and was surprised by a Chinese Amphibious Dock Ship that suddenly crossed its bow at a distance of less than 500 meters and stopped in the water, which forced the USS Cowpens to take evasive action to avoid a collision (ibid). But regardless of whose account was more realistic, again the scapegoat here was the US-China trust deficit, as such an incident, though not a novelty in the maritime interaction between the two nations since 1997, further deepened the mistrust gap between the two countries. If the "Cowpens Incident" showed anything, it clearly showed the silent cold war between an America that is pivoting towards Asia to consolidate its dominant position and a rising China which is deeply suspected to be working to undermine and even challenge the status quo.

Launching a Chinese aircraft carrier comes at a highly sensitive time, as China's neighbors have grown "increasingly concerned over the pace of the country's military build-up". China has even developed the DF-21D anti-ship ballistic 
missile, called the "Carrier killer" which is a unique land-based system that could potentially target moving ships hundreds of miles away as far as the Western Pacific Ocean. It is believed, especially in Taiwan, that "it is all about limiting the pre-eminent naval power in the region, the US, from intervening in any future crisis involving Taiwan" (Marcus, June 14, 2011, 1).

Furthermore, China is building its Chengdu J-20 stealth fighter, and tested it during a visit by former U.S. Defense Secretary Roberts Gates onJanuary11, 2011. Douglas Barrie, from the International Institute of Strategic Studies in London, says that the "unveiling of the Chengdu J-20 is believed to bring China into the restricted ranks of those countries able to build a fifth-generation radar-evading or 'stealth' fighter...[it also] does mark China's ambitions in terms of developing its air combat capability, and its defense aerospace industrial base" (Ibid), which could pose real hegemony challenges to its neighbors.

Slow but steady improvements in China's economic and military capabilities could lead to temptations to grow increasingly hegemonic, thereby creating diplomatic tensions and perhaps even armed conflicts in Asia. And this could cast further doubts as to whether China really wants to "play by the rules" and rise as a "responsible" actor, or as a vindictive "irresponsible" power that is willing to take whatever measures to assert itself regionally and globally. What Xi Jinping, the new leader in Beijing, during his tour in a military base in Guangzhou in December 2012, said to the PLA probably further deepened China's trust dilemma. President Xi urged the PLA to "revolutionize, modernize and standardize" its forces and to intensify its "real combat" awareness in order to be "able to fight and win a war absolutely necessary for a strong military" (Heesterman, 2016).

During the Xi Jinping era, PLA reforms have gone deeper and in a more substantial manner. "Xi Jinping mentioned during the military reform working conference that China's military organization structure must be modernized by placing the Central Military in direct control and creating new battle zone commands" (Chunshun, The Diplomat, December 5, 2015). The old region system is outdated, and to catch up with modern militaries, like the Japanese and American ones, the PLA needs to move to a battle-zones operability. A combination of indigenous defense development, military research and technology development has become mandatory for the PLA if it were to be ready for the South China Sea dangerous disputes. "From a structural perspective, the PLA's reforms are a move toward developing a specialized force and meeting the demands of the future battlefield" (Yu Lin, The Diplomat, March 7, 2016).

The Chinese military has undergone major overhaul since 2001, from a one relying essentially on high school manpower and dropouts to one recruiting educated cadres and emphasizing the need to acquire the most recent technological warfare and modern weaponry. The PLA was then described by former U.S. Assistant Secretary of Defense Chas W. Freeman Jr. as a "junkyard" force. "The last division of military regions in China was made in the 1950s, [and] there have been no strategic adjustments for more than 60 years" (Chunshun, The Diplomat, December 5, 2015). Though "by 2014, nearly 150,000 of the PLA's400,000annual recruits were college students and graduates, China's military has not adapted to the modern era" yet (ibid). Two major events raised the Chinese awareness to the rudimentary state of their uncompetitive military: the 1991 Gulf War and the 1996 Taiwan crisis (ibid).

Both the 1991 Operation Desert Storm and the1996 China-US showdown across the Taiwan Strait over the former attempting to disrupt Taiwan's first democratic elections, opened China's eyes to a bleak reality- the PLA was lagging way behind. Beijing also realized the value of modern weaponry and decided to undertake a modernization program of its military. The then-President Jiang Zemin decided a complete overhaul of the PLA which "began a modernization drive that continues today. This kicked off a spending spree from 1994 to 1999 during which China's defense budget more than doubled" (Moore \&Barreda, Foreign Policy, August 9, 2016).

With the second largest economy in the world, China's military budget has rocketed from just $\$ 20$ billion in 1989 to \$214 billion in 2015 - an amount larger than the military budgets of Russia, Germany and the United Kingdom combined. Stockholm International Peace Research Institute "estimates China's 2015 defense budget at \$214 billion, second in the world only to that of the United States. China's military spending constitutes 48 percent of the total spending of all the nations in Asia and Oceania combined" (Glaser, The National Interest, June 16, 2016). In 1990, China's military spending was less than \$10billion; it grew to more than $\$ 129.4$ billion in 2014, second only to that of the US" (Eikenberry, The American Interest, June 9, 2015).

China's 2004 Defense White Paper set two objectives for the PLA- defend China's sovereignty in both the South China and East China Seas, and to crush any independentist movement from Taipei. At an estimated but highly secretive military budget between 145 and 215 billion dollars over the last decade, the PLA has built "advanced ballistic missiles, various types of cruise missiles, nuclear submarines, modern surface ships, and an aircraft carrier; as well as additional advancement in the emerging areas of space, cyber, and the electromagnetic spectrum" (Glaser, The National Interest, 
June 16, 2016). The PLA is now building its second 50.000-ton-carrier in Northeast China with a ski-jump design for planes to take off and will for the first time be able to carry combat aircraft (ibid).

The second objective of the PLA regarding Taiwan's potential aspirations of declaring independence, and in view of its new Democratic Progressive Party (DPP) President's reluctance to recognize the 1992 Consensus (Note 12), Beijing believes it now has the diplomatic, economic and even military sticks that should prevent Taipei from contemplating any secessionist moves in the foreseeable future. The diplomatic quarantine of the Island, the huge trade and financial volume between the two sides which currently stands at more than 200 billion dollars, and as the risk of a Chinese-American conflict over Taiwan is a long way from being inevitable, all these variables would make the PLA think twice before it would contemplate any military adventure across the Taiwan Strait. As for Taiwan, it seems that, "like the rest of the world, [Taipei] has little choice but to engage with China, the world's most-populous country and second-largest economy" (http://money.cnn.com/2015/11/05/news/china-taiwan-trade-economy/). The Sino-Taiwanese intertwined relationship could mean that the fate of both economies are inextricably linked to each other, the role of unpredictable politics in the age of Donald Trump's presidency notwithstanding.

However, when exploring China's volatile security environment, it is hard to imagine a rising power standing idly before regional and world actors joining efforts and resources to prevent it from ascending to a global power status. Trying to ascend to such a world power position is not trouble-free for the Chinese because in their attempt to do so they paradoxically draw more suspicion from their neighbors as to their real intentions, which takes the discussion back to the central question of China's trust dilemma in its interaction with the United States and its own neighbors alike.

Historically, China does not have a history of invading its neighbors, its 1962 short war with India and its 1979 border war with Vietnam nevertheless. After all, "The Great Wall was built to keep the Mongol warriors and others out. The idea that after 5,000 years of history, China is all of a sudden going to start grabbing land with guns - it's just not part of the business model of the country's management" (Wiggin, "Invest...Not Invade", Daily Reckoning. February 1, 2013). Even though, China is growing economically and militarily, it is a far-fetched scenario to see the PLA tanks rolling downtown Phnom Penhor Yangon, Manila or Hanoi because of Beijing's territorial disputes especially with the last two capitals. Given the Philippines-U.S. military historical alliance and the new American cozying with Vietnam, neither the military balance nor the political and trade climate are in Beijing's favor for the unforeseeable future. It is clear that such an approach is not only incompatible with China's long-term interests, but also harms China's OBOR(Note 13) strategy and peripheral diplomacy (Xue, et. Al, The Diplomat, August 5, 2016).

Paradoxically, Beijing's "security" precautions, manifested in investing to modernize militarily, are construed by China's neighbors as "power"-building efforts with the potential to dominate. As Beijing's efforts to remedy its weak military position are perceived as a threat, it fits the key variable in this article- the paradox in the security dilemma deadlock. China is trying to build a modern military purportedly to protect its sovereignty, and the United States, together with most of China's neighbors, are looking at such developments with suspicion of a potential Chinese hegemonic penchant.

As a matter of fact, the United States has most of time dealt with China as a strategic challenge (Suskind 179-80, 188); except for periods of distraction such as the American reaction to the $9 / 11$ attacks and the consequents wars in Afghanistan and Iraq respectively in 2001 and 2003. The dichotomy between the reality of China's intents and how it is perceived has fuelled more doubts about Beijing's trust deficit in its relationship with Washington. Here, one can recall what Henry Kissinger once told Admiral Elmo Zumwalt in 1975 that America's approach to the Russians was seeking a modus vivendi with Moscow (Hanhimaki, 426-427). This simply meant that Washington was rather pragmatic in dealing with the Soviet Union, instead of trying to isolate the Russians from world affairs. Former Secretary of State Condoleezza Rice substantiated Kissinger's point with respect to the issue of China's rise. She said: "Now, the rise of China is something we don't only take note of, but we believe that there is an obligation by all of the powers, but perhaps particularly the United States, to engage in policies that will encourage ... the responsible stakeholder China, the China that sees it has an obligation in the international system to promote and, in fact, to defend peace and security" (China Daily, January 29, 2006).

\section{The Collision Course}

It seems that the United States seems to be in the process of developing almost the same sense of suspicion about China's rising power which the Spartans developed against the increasing military power of Athens, but which later brought about the Peloponnesian War in the $5^{\text {th }}$ century B.C. (Thucydides 1900). Then, what made war inevitable was 
the growth of Athenian power and the fear which that caused in Sparta. Now, what could make a Pacific showdown inevitable is not only China's growing power but also the fear it has been creating in America's security calculations.

Washington's primary concern regarding its relationship with China centers primarily on the strategic cost of China emerging as a great power for America's preponderant position, especially in East Asia. The current U.S.-China relationship is one between an established dominant superpower that is striving to prevent any rising actor to challenge the status quo and a rising power that is trying to assert itself and asking that its interests be taken into account in international and regional politics. Whether rising China is acting in self-interest or is embarking upon a complete revision of the existing international and regional order is something about intentions and therefore hard to measure, except for its alleged bullying behavior against its weak neighbors in the South China Sea.

China, however, has vowed that it would not militarize the disputed Spratly Islands, but according toRobert Cardillo, director of the National Geospatial-Intelligence Agency (NGA), a little known Pentagon spy service, Beijing has failed to live up to its pledge. Cardillo "told a recent U.S. congressional hearing that spy satellites and aircraft have been closely monitoring the island-building program by Beijing...[and] that we've identified military-related structures and equipment that at least give the Chinese the option to permanently post military forces in and on these islands" (Gertz, The National Interest, October 11, 2016).

Perceiving China as a bullying force, especially in the South China Sea has increased suspicion about its increasingly assertive and even hegemonic post-Cold War tendencies. At the same time, exaggerating the China-threat thesis in Japanese and South Korean eyes (DiFilipo 2002) is a common American practice. It seems that the United States needs to inflate the China trust gap in order to justify its encircling of the People's Republic with a chain of military alliances and bilateral accords to prevent the rise of a challenging China, such as the ones with Japan, South Korea, and the Philippines. According to documents released by Wikileaks after a suspected Russian hack, as one of the leaked emails from Hillary Clinton advisor John Podesta, Secretary Clinton privately told one group in a secret speech that the United States would "ring China with missile defense" if Beijing was unable to curb North Korea's nuclear program (The US and Global Security Review, http://newslinksandbundles.blogspot.com/2016/09/global-security.html).

Indeed, Washington has already encircled China with a series of bilateral and multilateral alliances, which go from the US-Japan alliance to the US-South Korea security treaty and the US-Philippines strategic relationship as well as the US-ASEAN special military and trade relationships, especially with Thailand and Singapore, and last but not least the US-Indian annual military drills. The other burgeoning alliance the United States has sought to build is with Australia where President Obama announced his new "Pivot-to-Asia"(Note 14) strategy back in November 2011. Explicitly identifying the Asia-Pacific region as a geostrategic priority for the United States, the Obama administration is paying a higher level of attention to the region across a wide range of issues" (Sutter \&et, Informal Institute for National Security Thinkers and Practitioners, September, 13, 2013).

Ostensibly, three unresolved strategic issues in the Sino-American relationship: North Korea's nuclear and missile programs, Beijing's assertive actions in the South and East China Seas, and the ongoing Chinese threat to Taiwan. In reality, however, the reason beyond the trust gap between the two countries is more strategic than regional. For the United States, American concerns relate to whether China will rise "responsibly" or as a challenger of the America's status quo. "China is building a wall of sand... the U.S. is throwing stones at this wall, and many were zeroing in on Beijing's response" (Sino-U.S. Competition and U.S. Security: How Do We Assess the Military Balance? Dan Blumenthal NBR Analysis. December 2010). In contrast, the bilateral and multilateral alliances the United States has built around China are viewed by Beijing as an attempt to contain China's rising power and to undermine its leverage in Asia, regardless of any consideration of Beijing's security concerns.

But what if THE UNITED STATES tried to understand China's defensive, and even psychological, motives in taking what is perceived as offensive postures? What if China had no offensive intentions in Asia, and it is just building enough power, by its own standards, to defend what it believes as its vital interests? After all, aren't offensive and defensive actions a matter of perception and intention? And isn't perception motivated by subjective and sometimes self-entertaining calculations? There is no objective unit of measurement for intentions. And in the context of China's trust dilemma with its neighbors and the West in general, "understanding China's future intentions, must include the understanding that [its] policies may not always be compatible with" Japanese, Indonesian and Filipino views, but not necessarily with an animus dominandi character (Brian, March 1997).

China may be and will be undertaking some actions to defend its own economic and trade interests in a volatile security environment such as that of Asia. According to Andrew Erickson, a China expert at the U.S. Naval War College, "China does not want to start a war, but rather seeks to wield its growing military might to 'win without fighting' by 
deterring actions that it views as detrimental to its core national interests" (Marcus, June 14, 2011). Moreover, according to a commentary posted in August 2015 by Xinhua, China's only aircraft carrier Liaoning was aimed simply at defending China's extensive coastline, and doesn't necessarily mark a shift in China's military capability or strategies (Miks, The Diplomat,August 10, 2011). China's new aircraft carrier may just be "a symbol of deterrence" more than a show of force or a manifestation of offensive intentions. After all, China still lags behind the US in technology and capability to execute missions of military projections.

Domestically, there are a few key variables which can be used as a hint to China's limitations of going hegemonic. China has its own domestic challenges to deal with and its own hurdles to surmount. State capitalism in China- a system in which political officials use state-run companies, privately owned national champion firms, state-owned banks and sovereign wealth funds- has generated growth, jobs and wealth (Bremmer,The National Interest, April 9, 2016). It has been at the heart of China's success for many years, and it will be central to China's development for some time to come. State-owned enterprises and the companies affiliated with them now account for more than half of China's output and more than half of its jobs (ibid). Their dominance is easy to document: in 2012, there were seventy mainland Chinese companies on the Fortune Global 500 list, and China's government owned sixty-five of them (ibid).

However, State capitalism has failed to keep with the pace of modern economic development and innovation; it has been rather static. China's economy has remained locked in the manufacturing-exporting corner, and failed to renovate into an added value service economy. Even when its economy surpasses that of the United States to become the world's largest economy, China will still be a relatively poor country with many unanswered fundamental questions about its future. It is true that China's single-party politics and its relative social stability have defied predictions about social instability for more than two decades, yet the Chinese Communist Party (CCP) ability to maintain relative stability over the near term should not lead us to underestimate the longer-term questions to come (Magnier, The Wall Street Journal, January19, 2016)

Experts, like John Mearsheimer, have been predicting for the last twenty-five years a hard landing for China's economy and a direct challenge to the Chinese Communist Party's governance (The National Interest, October 25, 2014). Hedge-fund manager Jim Chanos began warning in 2009 that the country's real-estate market had moved China's economy onto a "treadmill to hell." Also, Wei Yao, an analyst at French bank Société Générale, warned earlier this year that China might soon face a "Minsky moment," the point at which China collapses under the weight of the debts accrued by Chinese companies (Bremmer, The National Interest, April9, 2016). Gordon Chang, author of the 2001 book The Coming Collapse of China, argues that China's current slowdown is nothing less than China's "Lehman moment," a reference to the largest bankruptcy in U.S. history, that of the Lehman Brothers Bank in 2008. Whatever the imbalances in China's economy, however, they are unlikely to bring about "regime-threatening levels of unrest in the near future because three decades of go-go growth and swelling national pride provide leaders with considerable political capital" (Gvosdev, p.1).

China's long term objective of a Xiaokang (Note 15) society by 2020 still has a long way to go, as the Chinese economy is facing many challenges. For the time being, as China suffers from chronic inequalities between urban and rural population in income, health and education opportunities, Beijing has two major priorities in the near future. The first is to continue to expand economically into more foreign markets and to maintain a consistent growth rate of approximately 7 per cent in order to be able to address the development imbalances between the countryside and big business centers, such as Shanghai and Beijing. More than 130 million poor people, mostly in the countryside, still live under the poverty line according to the World Bank Purchasing Power Parity (PPP) statistics, and still complain about the old-fashioned Hukou (Note 16) system (Brenner, April 2002).

In his 2016 book China's Future, David Shambaugh goes further to link any social and economic stability to some kind of political openness by the CCP. For the first time in six years China's 2015 economic growth fell below the seven per cent threshold which is the minimum to maintain a safe job-creating labor market. Worse than that, most independent estimates forecast growth averaging just less 6 per cent; a rate that could have economic and even political ramifications as to the CCP political grip on power. Failing to live up to its repetitive promise to provide for a «well-off » society could threaten the core of the CCP political legitimacy (The Economist, "China's financial system: the coming debt bust", May 7th 2016).As "the main elements of the broad reform program first launched by Deng Xiaoping in 1978 are no longer applicable or sustainable", it will not be without any political cost to the CCP for the next decades (Tiezzi, The Diplomat, May 17, 2016). In an interview by the Diplomat, David Shambaugh argues that "by staying on its current course, I predict that economic development will relatively stagnate and stall, exacerbating already acute social problems, and producing the protracted political decline over time of the ruling Chinese 
Communist Party"(Tiezzi, The Diplomat, May 17, 2016).

Continuing its denial strategy that China's rigid economic path of communist capitalism -control of the financial system of the state owning the major banks and most of their biggest debtors- is on the right course would highly likely lead to the system collapse sooner rather than later. Such bleak scenario would have meteoric consequences not only for China but also for the region's stability, hence the relevance of the American role in handling the debris of China's potential socio-economic bang. To avert such a scenario, Beijing's immediate focus for the unforeseeable future is to "increase the legitimacy of the Chinese Communist Party (CCP), enhance governance capabilities, promote the establishment of a service-oriented government in order to maintain social stability, restructure the economy, promote sustainable development, and improve social welfare" (Li and Yanzhuo, The Diplomat, August 05, 2016).

Moreover, China's dependence on the outside world is another key variable to reflect on. It has an economy with enormous demand and tremendous potential, which increases its need to its neighbors' markets and technological know-how. The depth and interconnectedness of the Sino-Japanese economic and trade exchange, for example, could be a hedge against any deterioration in the political relationship between the two giant neighbors. A Sino-Japanese war, for instance, would be disastrous for the Chinese economy. China would suffer if Japanese companies pull out of the Chinese market, because up to five million Chinese workers would lose their jobs at a time Xi Jimping looks to double per capita income by 2020. After all, China does not operate in a vacuum; it will always need its periphery as well as its remote partners. Besides, China has heaps of unresolved domestic issues to confront; its myriad of economic, social and even political challenges ahead are not something to underestimate.

Today, with all these socio-economic headaches looming ahead in the Chinese Communist Party and the political cost they may entail, Beijing is hardly focused on projecting its power, even regionally. As a clear beneficiary of economic globalization, Beijing "has an obvious 'national interest' in preserving access to global markets" (Gilley, 795-811). A few years before the 2020 target date, China, even with an unsustainable growth rate, has already proven par excellence to be the hub of East Asia's economic prosperity and financial stability over the last two decades or so.

Therefore, whether focusing on China's military capabilities or a combination of its intentions and capabilities, China is still a conservative, middle power that may not really matter to the degree that the coming-conflict-with-China camp has advanced (Bernstein and Munro 25), leading this article to argue that one ought to be aware of the dichotomy between perceptions of a China threat and the reality of a developing nation that is striving to feed hundreds of millions of its 1.3 billion population for a long time to come. Objective indicators, social, economic, ethnic be they, all point out to the fact that "despite the outward appearance of a country with a strong, growing economy possessing a capable, upgrading military, China's internal position is still one of turmoil and metamorphosis. Just as China's past was troubled with internal disorder, its present is characterized by numerous economic, social, environmental, and political problems which may hamper her rise to world status" (Simpson, The Research Department, Air Command and Staff College, March 1997).

With regard to capabilities and intentions, there are two points to be made here. First, nations do not have to be intentionally aggressive to pose a security threat. John Garver warns of security dilemmas wherein nations arm to defend themselves against what might happen (Garver quoted in Pumphrey (ed), January 2002). In so doing, they become a threat to their own neighbors, regardless of whether or not they have aggressive designs against them. In short, capabilities are a threat, regardless of intentions. So, China's trust dilemma could turn out to be a security dilemma that reflects a sense of insecurity more than the desire to dominate others. Second, the perception of threat can matter as much as the reality. Emerson Niou notes the significance of perception in the standoff between the People's Republic of China and Taiwan. The perception of what the United States will or will not do to defend Taiwan, for instance, plays a crucial role in determining how far China and Taiwan are prepared to go in challenging the status quo (Niou quoted in Pumphrey (ed), January 2002). Therefore, China analysts ought to recognize the difficulty of determining intentions when judging and sometimes pre-judging China.

Realistically, China still lacks the capabilities to seriously threaten the security of its neighbors, and its intentions are probably more inclined toward maintaining the regional status quo, at least for the time being. China still lacks the necessary inventories of power to project its influence regionally or globally, and it does not seem likely to develop such capabilities in the immediate future. Former U.S. Deputy Secretary of Defense Joseph Nye believes that "if Chinese military "modernization" continues at its current rate, in twenty years it will have the capabilities of a mid-level U.S. NATO ally of forty years ago" (Gerson, Lecture June 26-27, 1999). Now in 2016 China is almost a match to a NATO military power qualitatively and not quantitatively (Rinehart. "The Chinese Military: Overview and Issues for Congress", Congressional Research Service. March 24, 2016). 
So far, the Chinese military has been postured primarily toward defending the Chinese mainland from attack, dating back to the "people's war strategy" of the Mao era (Note 17). "To bid for mastery of East Asia, China will have to fundamentally transform the doctrine, training, and structure of its military, which has traditionally focused on defending home territory" (Schwarz 27), yet again this is all about intentions. "Externally, [Beijing] supports and maintains the existing international system and even dedicates China's efforts to improving the system by creating functional mechanisms and enhancing the role of emerging economies. Take the Asian Infrastructure Investment Bank (AIIB) as an example - China has operated the bank in cooperation and collaboration with the existing global and regional programs" (Xue, et. Al, The Diplomat, August 5, 2016). While China wants to have its interests taken into account by the countries in East Asia, it does not necessarily mean that China will automatically seek to dominate its neighbors the way the Soviet Union did in Eastern Europe, for example.

\section{Conclusion}

The perceived China threat remains relative. Criticism of China's bullying conduct in the South China Sea may be exaggerated. First, the disputed Spratly islands do not form a part of the core territories of any of the claimant states, which means that they are not an imminent security problem to the region; they are of peripheral not core risk to regional security (Whiting,1995). Second, China no longer poses a political challenge to the claimant states as it did in the 1950s and 1960s. Then, China sought to undermine the political regimes of many of these states by supporting of communist insurgencies. The most prominent case was the 1962 Indonesian aborted coup instigated by the Indonesian Communist Party sanctioned by Beijing. Today's East Asian politics has changed, and China is no longer after exporting communism to its neighbors as it did in the 1960s.

Therefore, it is true that China is the biggest exporter in the world, has the largest foreign exchange reserves, has record trade surpluses with most of the large economies in Asia, America and Western Europe, but all these superlatives paradoxically hide China's own vulnerabilities. This is a good reason why rising nations like China ought not to be judged by their outward appearances, be they financial, economic, and even military. That is why it is highly likely that China's controversial actions both in the East and South China Seas, "without proof to the contrary, will continue to stem from attempts to improve its world status and provide a viable defense of its own security. Efforts to modernize militarily could simply be indicative of China's desire to keep pace with other potential and known world powers" (Simpson, The Research Department, Air Command and Staff College, March 1997). While these incidents and their subsequent developments have played well into the fears of some of the China-threat thesis, these fears may be exaggerated, at least for now. The debate about the perceived China threat is dominated by hardliners and moderates in Asia, especially in the United States; those who see in China a hegemon on the horizon, and those who advocate more caution in pre-judging China at this point.

In the final analysis, faced with the domestic problems stemming from an uncontrollable population growth, pollution, urbanization, ethnic and social unrest, and cornered by an ostensibly unfriendly security environment in Asia, China could turn more and more coercive as a way to cover up its internal shortcomings. In fact, building power projection capabilities may tempt China to demonstrate its strength abroad as it becomes shaky at home which explains why it is imperative for the advocates of the China-trust deficit to understand that they must be very cautious in making predictions about China's future intents. Yet again there are those who espouse what former President Ronald Reagan once said about dealing with the ex-Soviet Union- trust but verify (Pinkerton2016).

In the end, the overall stability of the Asian region will largely depend more on Beijing's intentions than on its capabilities. That's why this work considers not only the realities of China's rise, but also its perceptions, which are often the driving force of East Asian politics. Now, the fear of the rising power of China has triggered a unique sense of insecurity in Asia at large; this is because Asia, at its core, is an insecure region with a lingering history of unresolved wartime controversies, with a nod to Joseph S. Nye, Jr.

\section{References}

Andrews, P. (2006). China's energy and environmental policies and their implications for OPEC, Speed Centre for Energy, Petroleum and Mineral Law and Policy: University of Dundee.

APO Production Data book (2012), Asian Productivity Organization, 15-32. Retrieved from http://www.apo-tokyo.org/publications/files/ind_APO_Productivity_Databook_2012.pdf

Asia Times online. Retrieved September 16, 2010, from http://www.atimes.com/atimes/China/LI16Ad02.html 
Asia-Pacific (2011, June 8). BBC News. Retrieved from http://www.bbc.co.uk/news/world-asia-pacific-13693495

Bernstein et alt. (1998). The Coming Conflict with China. Vintage: Reprint edition.

Bottelier, P.P. (2005). China's Economic Rise- What Does it Mean for the U.S. and for the World. School of Advanced International Studies: John Hopkins University.

Bracknell, Butch. (2014). Of Course States Spy on States. The Diplomat. Retrieved September 08, 2014 from http://thediplomat.com/2014/09/of-course-states-spy-on-states/

Bremmer, I. (2016). China: Superpower or Superbust? The National Interest. Retrieved from http://nationalinterest.org/blog/the-buzz/china-superpower-superbust15735?page=2\&keepThis=true\&TB_ifram $\mathrm{e}=$ true\&height $=900 \&$ width $=600 \&$ caption $=$ China $\% 3 \mathrm{~A} \% 20$ Superpower $\% 20 \mathrm{of} \% 20$ Superbust $\% 3 \mathrm{~F}$

Brenner, M. (2002). Defining and Measuring a Global Living Wage: Theoretical and Conceptual Issues. Political Economy Research Institute: University of Massachusetts.

Brian A.S. (1997). China's Future Intent: Responsible World Power or International Rogue State: The Research Department, Air Command and Staff College.

Burton, S, et al. (March, 1997). The Next China. Time, 52.

Chestnut \& Johston, (2009). Quoted in Global Giant: Is China Changing The Rules of The Game? Edited by Paus, et alt, Palgrave Macmillan, 237-260.

China in Africa Project: Publications, South African Institute of International Affairs. Retrieved from http://www.saiia.org.za/china-in-africa-project/china-in-africa-project-publications.html

China-Japan economic, Trade Ties have Great Potential to Tap. (2010, August 22). China Daily. Retrieved from http://www.chinadaily.com.cn/bizchina/2008-05/05/content_6661446.htm

Christensen, J. T. (2015, July 22). The China Challenge. The New York Times. Retrieved from http://www.nytimes.com/2015/07/26/books/review/the-china-challenge-by-thomas-j christensen.html?_r=0

Chunshan, Mu. (2005).The Logic Behind China's Military Reforms. The Diplomat. Retrieved December 05, 2015 from http:/thediplomat.com/2015/12/the-logic-behind-chinas-military-reforms/

Diaoyu, S. (2011). Small Islands - Big Problem: and the Weight of History and Geography in China-Japan Relations, The Asia Pacific Journal. Retrieved from http://www.japanfocus.org/-gavan-mccormack/3464-

Difilippo. A. (2002). The Challenges of the U.S.-Japan Military Arrangement: Competing Security Transitions in a Changing International Environment. Armonk, N.Y.: M.E. Sharpe.

Dingli et alt. (2016). China's Maritime Disputes, A Council on Foreign Relations Info Guide Presentation. Retrieved from http://www.cfr.org/asia-and-pacific/chinas-maritime-disputes/p31345\#!/p31345

Duong, H. (2011, July 20). Negotiating the South China Sea. The Diplomat.

Duong, H. Negotiating. (2011, July 20). The South China Sea. The Diplomat.

Eikenberry. K. W. (2015, June 9). China's Place in US Foreign Policy. The American Interest, 10. Retrieved Nbr.6 $19^{\text {th }}, 2010$ from http://www.the-american-interest.com/2015/06/09/chinas-place-in-u-s-foreign-policy/

Emerson, N. (2002, January). The US Security Commitment to Taiwan Should Remain Ambiguous, quoted in Carolyn W. Pumphrey, The Rise of China in Asia: Security Implications: Dane Publishing.

Ferguson, F. (2011, August 14). Gloating China, Hidden Problems. The Daily Beast. Retrieved from http://www.thedailybeast.com/newsweek/2011/08/14/china-faces-its-own-fiscal-problems.html

Finan, W.W. Jr. (September 2011). China and East Asia: China According to Henry. Current History.

Garver, J. (January 2002). The Gestalt of Sino-Indian Relationship. In Carolyn W. Pumphrey (ed.), The Rise of China in Asia: Security Implications: Dane Publishing Books.

Gerson. (1999). Fresh Look: Re-examining the role and impact of U.S. bases in Asia-Pacific, Lecture, June 26-27,

Gertz, B. (2005). The China Threat: How the People's Republic Targets America. Washington, D.C.: Regnery Publishing, Inc.

Gertz, B. (2016, October 11). China's South China Sea Island Buildup for Military Purposes. The National Interest. Retrieved from http://nationalinterest.org/blog/the-buzz/chinas-south-china-sea-island-buildup- $\% \mathrm{E} 2 \% 80 \% 98$-military-purposes 
$\%$ E2\%80\%99-18006?page=show

Gilley, B. (2011). Beyond the Four Percent Solution: Explaining the Consequences of China's Rise. Journal of Contemporary China, 20(72), 795-811. https://doi.org/10.1080/10670564.2011.604501

Green,M. J. (2013, December 2). Safeguarding the Seas: How to Defend against China's New Air Defense Zone, Foreign Affairs. Retrieved from https://www.foreignaffairs.com/articles/china/2013-12-02/safeguarding-seas

Gvosdev, N. (October 2013). The Realist Prism: U.S. MustBePrepared for Change in Global Partnerships. World Politics Review. Retrieved from http:/connection.ebscohost.com/c/articles/91689466/realist-prism-u-s-must-be-prepared-change-global-partners hips

Hanhimaki, J. (2004). Flawed Architect: Henry Kissinger and American Foreign Policy: Oxford.

Harrison, S.S. (2002), Toward Oil and Gas Cooperation in Northeast Asia New Opportunities for Reducing Dependence on the Middle East. Asia Program Special Report, NO. 106.

Hatch, J. K. (2002). Innovations from the Field, A Daringly Brief Summary of a Huge Phenomenon: Sara R. Levine \& Amanda Penn. Retrieved from www.microcreditsummit.org/papers/innovations_final.doc

Heesterman, A.R.G. (2013). Rediscovering Sustainability: Economics of the Finite Earth. Routledge; New edition. (January 16, 2013).

Holodny, E. (2015, August 18). Here are the various ways the US depends on China, Business Insider. Retrieved from http://www.businessinsider.com/metrics-of-us-dependence-on-china-2015-8

$\mathrm{Hu}$ Jintao's boastful speech on war 'victory' commemoratio, (2005, September 3). Retrieved from http://www.hkfront.org/sjw60speech-en.htm

Johnson, Chalmers. (2004). The Sorrows of Empire: Militarism, Secrecy, and the End of the Republic. New York: Metropolitan Books.

Johnston, A. (2008). Social States: China in International Institutions 1980-2000. Princeton Studies in International History and Politics. Retrieved http://samples.sainsburysebooks.co.uk/9781400852987_sample_942954.pdf

Kanji, O. (2003). Security in Burgess. In G. and H. Burgess (eds.), Beyond Intractability. Conflict Research Consortium: University of Colorado.

Kim, (1996, July 29). China's Quest for Security in the Post-Cold War World. The U.S. Army War College, Seventh Annual Strategy Conference: the Strategic Studies Institute.

Krishnappa, V. (2012). Grand Strategy for India 2020 and Beyond. Institute for Defense Studies \& Analyses: New Delhi, 13-40.

Magnier, M. (2016, January19). As Growth Slows, China Highlights Transition from Manufacturing to Service. The Wall Street Journal. Retrieved from http:/www.wsj.com/articles/as-growth-slows-china-highlights-transition-from-manufacturing-to-service-14532 21751

Malik, Mohan. (2014). China and Strategic Imbalance. The Diplomat. Retrieved July 14, 2014 from http://thediplomat.com/2014/07/china-and-strategic-imbalance/

Marcus, J. (2011, June 14). China extending military reach,BBC News Asia. Retrieved from http://www.bbc.co.uk/news/mobile/world-asia-pacific-13761711

MD: Rowman and Littlefield Publishers, 2010.

Miks, J. (2011, August 10). China Launches 1st Carrier. The Diplomat.

Miller, J. B. (2012). China's Other Territorial Dispute: Baekdu Mountain. Retrieved from http://thediplomat.com/2012/12/21/baekdu-mountain-chinas-other-territorial-dispute/

Miller, K. (2010). A member of the U.S. State Department's Advisory Committee on International Economic Policy, Foreign Affairs.

Mills. I. China's Colonial Past Key to Understanding its Future. World Politics.

Moore \& Barreda. (2016, August 9). Foreign Policy. 
National Bureau of Statistics. (2016, July 15). China GDP Annual Growth Rate 1989-2016.http://www.tradingeconomics.com/china/gdp-growth-annual.

Nye, J. S. Jr. (2015, April 3). The China Challenge. The Boston Globe.

Pinkerton, J. P. Trump's Mission (2016). Make America Great Again. Peace with Honor-Through Deal-Making. Retrieved November 22, 2016 from: http://www.breitbart.com/2016-presidential-race/2016/05/21/trumps-mission-make-america-great-2/

Pro-Active Policies by China in Response to Asian Financial Crisis. Retrieved from http://www.fmprc.gov.cn/eng/ziliao/3602/3604/t18037.htm

Pumphrey, C. W. (2002). Power shift: rethinking Australia's place in the Asian century. Australian Journal of International Affairs, Special Issue: Is Australia ignoring Japan, 65(1), 81-93.

Responding to the Economic Crisis -Coherent Policies for Growth, Employment and Decent Work in Asia and Pacific (2009), International Labor Organization (ILO), Manila, Philippines, 18-20, Retrieved from http://www.ilo.org/public/libdoc/ilo/2009/443695.pdf

Reynolds, P.A. (1994). An Introduction to International Relations ( $3^{\text {rd }}$ ed.). London \& New York: Longman.

Rinehart, I. E. (2016, March 24). The Chinese Military: Overview and Issues for Congress. Congressional Research Service. Retrieved from https://www.fas.org/sgp/crs/row/R44196.pdf

Rosenberg, D. (2002). The Rise of China in Asia: Security Implications. Ed. Carolyn W. Pumphrey. Strategic Studies Institute, U.S. Army War College.

Sanger et Al. "New Photos Cast Doubt on China's Vow Not to Militarize Disputed Islands".

Santolan, J. (2011, May 11). 18th ASEAN summit held amid growing geopolitical tensions World Socialist Web Site. http://ki-media.blogspot.com/2011/05/18th-asean-summit-held-amid-growing.html.

Santolan, J. 18 $8^{\text {th }}$ ASEAN summit held amid growing geopolitical tensions, World Socialist Web Site, 11 May 2011

Scott. D. (2008). The 21st Century as Whose Century?,Journal of World-Systems Research (JWSR), 96-118.

Shuman, F. L. (1953). International Politics ( $5^{\text {th }}$ ed.). New York: McGraw-Hill Book Co.

Sutter \&et, (2013, September 13). Balancing Acts: The U.S. Rebalance and Asia-Pacific Stability. Informal Institute for National Security Thinkers and Practitioners.

Sutter, R. G. (2010). U.S-Chinese Relations: Perilous Past. Pragmatic Present. Lanham.

Thayer, C. A. (2001). ASEAN Ten Plus Three: An Evolving East Asian Community. Comparative Connections.

The New York Times. Retrieved August 8, 2016 from http://www.nytimes.com/2016/08/09/world/asia/china-spratly-islands-south-china-sea.html

Ting, G. (March 30, 2016). US Upgrades Economic Ties with ASEAN amid China's Growing Influence, The Diplomat. Retrieved from http://thediplomat.com/2016/03/us-upgrades-economic-ties-with-asean-amid-chinas-growing-influence/

Trans, B. J. (1900). Thucydides. History of the Peloponnesian War ( $2^{\text {nd }}$ ed.). London: Oxford University Press.

Treverton, Gregory. F.J., \& Seth G. (2005). Measuring National Power, The RAND Corporation. Retrieved from http://www.rand.org/pubs/conf_proceedings/CF215.html

Trinity RS Series, Wake Round 8 - Trinity RS File Name 2013-2014 1 1AC. Retrieved from https://www.coursehero.com/file/10228842/Wake-Round-8/.

United Nations Department of Economic and Social Affairs. (2011). Population Division Population Distribution, Urbanization. Internal Migration and Development: An International Perspective, 81-109.

Walters, R. (2016, April 15). Philippines v. China: The ADIZ Menace, The National Interest. Retrieved from http://nationalinterest.org/feature/philippines-v-china-the-adiz-menace-15791

Welch, D. A. (2013, December 9) What's an ADIZ? Why the United States, Japan, and China Get It Wrong. Retrieved from https://www.foreignaffairs.com/articles/east-asia/2013-12-09/whats-adiz

Whiting, A.S. (1995). East Asian Military Security Dynamics. The Asia/Pacific Research Center, the Board of Trustees of the Leland Stanford Junior University. 
Wiggin, A. (2013, February 1). Invest...Not Invade. Daily Reckoning.

Winterford, D. (1993). Chinese Naval Planning Maritime Interests in the South China Sea: Implications for US and Regional Security Policies. Journal of American East Asian Relations, Winter, 369-98.

World Survey of Energy Resources, World Energy Council 2007, Retrieved from http://www.worldenergy.org/documents/ser2007_final_online_version.pdf

Xue et al. (2016, August 5). How the US Misjudged the South China Sea, Part I. The Diplomat. Retrieved from http://thediplomat.com/2016/08/how-the-us-misjudged-the-south-china-sea-part-ii/

Xue, L., \& Yanzhuo, X. (2016, August 05). How the US Misjudged the South China Sea, Part II. The Diplomat. Retrieved from http://thediplomat.com/2016/08/how-the-us-misjudged-the-south-china-sea-part-ii/

Ying. Y. L. (2016, March 7). The Implications of China's Military Reforms. The Diplomat. Retrieved from http://thediplomat.com/2016/03/the-implications-of-chinas-military-reforms/

Zhang, Y. (2011, December 28). Wall Street Journal. Retrieved from http://online.wsj.com/article/SB10001424052970204296804577124343176436540.html

Zumwalt, E. R. (1976). On watch: A memoir Quadrangle( $1^{\text {st }}$ ed.). New York Times Book Co.

Zweig, David, \& Jianbai. (2005). China's Hunt for Energy. Foreign Affairs, 84(5).

(2009, December 12). Changing Perception of U.S. Policy towards China under Obama. Mainstream, $X L V I I(52)$.

\section{Anonymous}

(2010, December 24), China blocked exports of rare earth metals to Japan, The Telegraph, http://www.telegraph.co.uk/finance/china-business/8022484/China-blocked-exports-of-rare-earth-metals-to-Jap an-traders-claim.html).

(2011, July 29), China Slams U.S. Over debt Impasse, The Wall Street Journal.

(2011, July 29), China Slams U.S. Over debt Impasse, The Wall Street Journal.

(2016, May 7), The Coming Debt Bust, The Economist. Retrieved on October 11, 2016 from: http://www.economist.com/news/leaders/21698240-it-question-when-not-if-real-trouble-will-hit-china-comingdebt-bust.

(2016, May 7). China's financial system: the coming debt bust, The Economist. Retrieved on November 17, 2016 from:

http://www.economist.com/news/leaders/21698240-it-question-when-not-if-real-trouble-will-hit-china-comingdebt-bust.

\section{Notes}

Note 1. Survey by the Pew Research Center, "Chinese Public Sees More Powerful Role in World, Names U.S. as Top Threat", October 5, 2016, http://www.pewglobal.org/2016/10/05/chinese-public-sees-more-powerful-role-in-world-names-u-s-as-top-threat/.

Note 2. Purchasing Power Parities and Real Expenditures of World Economies, Summary of Results and Findings of 2011 International Comparison Program», International Comparison Program, 2011, International Bank for Reconstruction and Development, the World Bank, http://siteresources.worldbank.org/ICPEXT/Resources/ICP_2011.html.

Note 3. BREE 2014, Resources and Energy Quarterly, March Quarter 2014, BREE, Canberra, March 2014.

Note 4. Keck, "In America, China is Public Enemy \#1", The Diplomat, February 27, 2014.

Note 5. The Treaty of Wanghia was signed between the United States and China in 1844 when the latter was under European colonization during most of the $19^{\text {th }}$ century. Caleb Cushing, sent by the then President Tyler, was the American negotiator who pressured the Chinese government to sign for American extraterritoriality in China, which was the most humiliating clause of the treaty for the Chinese, and was later the main cause of many anti-Western rebellions, such as the Boxer Rebellion in 1899. The extraterritoriality clause meant that only U. S. Consul officials 
could try Americans for crimes committed in China. The treaty secured the same rights for the United States that European nations had received from the Chinese. Cushing was successful gaining those same rights for the United States. This treaty also overturned an old Chinese law that forbade foreigners from learning the Chinese language.

Note 6. A security dilemma situation is when state A takes action to enhance its own security, but paradoxically endangers the security of other states which in their turn react by engaging in countermeasures which would be construed as threatening by State A.

Note 7. Retrieved from: http://www.mycentx.com/news/china-warns-us-surveillance-plane.

Note 8. Cary Coolidge, "The Groupings of Nations", Foreign Affairs, Volume 5, Number 2. January 1927. Retrieved from: https://www.foreignaffairs.com/articles/1927-01-01/grouping-nations.

Note 9. John Mearsheimer's Speech for The Centre for International Policy Studies, Ottawa, "Why China Cannot Rise peacefully", https://www.youtube.com/watch?v=CXov7MkgPB4.

Note 10. For more on the security and strategic implications of China's rising economic competitivity, see China Security Review Commission, Report to Congress of the US-China Review Commission- The National security Implications of the Economic Relationship between the united States and China, July 2002, Chapter 8, 5)

Note 11. China's nine-dash line was first created by the Nationalist Chinese government in 1947. It is a boundary that is the basis for China's 69-year-old claim to almost $85 \%$ of the South China Sea where Beijing has territorial disputes with Vietnam, Malaysia, Indonesia, Brunei, the Philippines and Taiwan. The Nine-Dash Line was the subject of a ruling in July 2016 by the Hague-based international tribunal which found that Beijing's self-proclaimed nine-dash line in the South China Sea had no legal basis.

Note 12. The 1992 Consensus was signed on July 31, 1992 in Singapore by the heads of the two associations representing Beijing and Taipei during President Lee Teng-hui's first term1988-1996. The document stipulated that Taiwan and China agree that there is only one Chinese nation comprising all of mainland China, Taiwan, but they also agreed to disagree on the definition of control of the two states in Taiwan and the China mainland.

Note 13. The Silk Road Economic Belt and the 21st-century Maritime Silk Roador the One Belt One Road (OBOR) is China's most ambitious foreign economic development initiative which aims to recreate the legendary Silk Road. It was President Xi Jimping who came up with the idea to reinvent this old project. OBOR consists of two main components, the land-based "Silk Road Economic Belt" (SREB) and oceangoing "Maritime Silk Road" (MSR). This enormous project sought connectivity and cooperation between China and the rest of Eurasia. OBOR means a China's push to take a bigger role in global affairs.

Note 14. President Obama announced from Canberra, Australia, in 2012 his major foreign policy approach-The "pivot to Asia". It is a strategic decision to 'pivot' or 'rebalance' politically and militarily to the Asia-Pacific region as the United States was withdrawing large troop deployments from the Middle East and South Asia. The "pivot to Asia" means that the United States has been extending and deepening its regional military alliances purportedly to contain China and confront Russia in the Pacific.

Note 15. It was Deng Xiaoping who used xiaokang in 1978 and who set it as a goal to be attained by the Chinese nation by the end of the 20th century. Xiaokang literally means "small well-being" in a social state in which people lead a fairly comfortable life. The term has a long history. It was mentioned in the Book of Songs 2000 years ago.

Note 16. China enacted the Hukou System soon after the foundation of the People's Republic of China to prevent a large influx of rural workers to the cities looking for higher paying jobs. It was meant to create economic stability between the country's large rural farming population and the growing urban areas. The Hukou System has effectively limited the amount of rural-urban migration because rural Chinese have to give up their healthcare, education and social security if they decide to move to cities.

Note 17. For more on Mao's Doctrine, see "Transformation and Refinement of Chinese Military Doctrine: Reflection and Critique on the PLA's View" by Alexander Chieh-cheng Huang, CSIS and the University of Maryland. 